\title{
RESEARCH PAPER \\ THE EFFECTS OF ASPECT RATIO ON SOLAR ENHANCED WASTE STABILIZATION PONDS
}

\author{
J. T. Utsev ${ }^{1}$ and J. C. Agunwamba ${ }^{2}$ \\ ${ }^{I}$ Department of Civil Engineering, University of Agriculture, Makurdi-Nigeria. \\ terlumunutsev@yahoo.co.uk \\ ${ }^{2}$ Department of Civil Engineering, University of Nigeria, Nsukka, Nigeria. \\ jcagunwamba@yahoo.com
}

\begin{abstract}
:
The simulation of solar radiation in waste stabilization ponds is a developing tool worth studying in order to understand its effects on wastewater quality in waste stabilization ponds. Hence, the research is aimed at investigating the effect of length to width ratio $(L / W)$ in solar enhanced waste stabilization ponds (SEWSPS) treatment efficiency. SEWSPs of varying sizes made of metallic tank with inlet and outlet valves, and a solar reflector was constructed to increase the incident sunlight intensity. Wastewater samples collected from the inlet and outlet of the SEWSPS were examined for physico-chemical and biological characteristics for a period of twelve (12) months. The parameters examined were Temperature, $\mathrm{pH}$, detention time, total suspended solids, dissolved oxygen, biochemical oxygen demand $\left(\mathrm{BOD}_{5}\right)$, chemical oxygen demand $(\mathrm{COD})$, algae count, faecal coliform and E-Coli. The efficiencies of the SEWSPs with respect to these parameters fluctuated with width variation, with the smallest SEWSP in width giving the highest treatment efficiency. The research revealed that with the incorporation of solar radiation in WSPs, a length/ width ratio of 1:0.2 should be used in the design of SEWSPs for maximum treatment efficiency.
\end{abstract}

Keywords: waste stabilization pond, efficiency, solar radiation, aspect ratio, wastewater.

\section{INTRODUCTION}

A solar enhanced waste stabilization pond is a new technology that evolved as a result of the incorporation of solar reflectors in the conventional waste stabilization pond for the purpose of increasing the efficiency and reducing the land area requirement of waste stabilization ponds (Agunwamba et al., 2009). For a rectangular waste stabilization pond (WSP), the aspect ratio denotes the ratio of length to width of the WSP, usually a minimum of $2: 1$ is recommended (Marais, 1966).
Solar energy comes to earth in the form of waves of radiation or waves of photons possessing varying amounts of energy and travelling at uniform speed of $3 \times 10^{8} \mathrm{~m} / \mathrm{s}$. The wavelength of these waves depend upon the extent of that energy; the more energy a group of photons possesses, the shorter the wavelength and vice versa. The entire content of this radiation is called the solar spectrum. At the lower end of the solar spectrum are the low frequency invisible wavelengths called infrared, which make up nearly half of the sunlight reaching the earth 
(Strong and Scheller, 1993). Next to this is the visible spectrum, with wavelengths growing progressively shorter from red to violet. Once the infrared and visible spectrums are accounted for, only 5-7\% of solar spectrum remains. The remaining part is the ultraviolet radiation. Their wavelength is the shortest and they therefore have the highest amount of energy which plays the role of water and wastewater treatment (Benchokroun et al., 2003).

The most appropriate wastewater treatment is that which will produce an effluent meeting the recommended microbiological and chemical quality guidelines both at low cost and with minimal operational and maintenance requirements. Different systems are used worldwide for wastewater treatment such as activated sludge, trickling filter and waste stabilization pond systems. Pond systems are commonly employed for municipal sewage purification, especially in developing countries, due to its cost effectiveness and high potential of removing different pollutants (Arar, 1988; Christian et al., 2003).

WSPs are designed to achieve different forms of treatment up to three stages in series, depending on the organic strength of the input waste and effluent quality objectives. Usually, classical WSPs consist of an anaerobic pond, followed by primary or secondary facultative ponds. If further pathogen reduction is necessary, maturation ponds will be introduced to provide tertiary treatment. WSPs are very widely used for small rural communities but large systems exist in Mediterranean basin, France and also in Spain and Portugal. However, in warmer climates (the Middle East, Africa, Asia and Latin America) ponds are commonly used for large populations (Hamzeh and Pronce, 2002).

In developing countries and especially in the tropical and equatorial regions like Nigeria, no wastewater treatment systems are observed in rural communities. There is a great need for wastewater treatment systems to avoid the health risk problems in these communities (Agunwamba, 2006). Wastewater treatment by WSPs has been considered an ideal way of using natural processes to improve wastewater effluents ( Shelef et al., 1987; Sarikaya et al., 1987 and Polprasert et al., 1983). In natural treatment systems such as WSP, the pathogens are progressively removed along the pond series with the highest removal efficiency taking place in the maturation ponds (Mara and Pearson, 1998). Although solar inactivation of bacteria in wastewater is well established (Sinton et al., 2002; Benchokroun et al., 2003; DaviesColley et al., 2005), the efficiency and economics of integration of solar reflectors in ponds has also been investigated(Agunwamba et al., 2009). Hence, the aim of this study was to determine the optimum length to width ratio for the design of solar enhanced WSPs for more efficient wastewater treatment.

\section{MATERIALS AND METHODS Physical Pond Design}

The study was conducted using a 1:20 scale model of a conceptualized prototype waste stabilization pond. Geometrical similarity was applied for the design of the scale model pond. The design was performed first using Froude number similarity and compared with Reynold's number. The ratios that must exist between the model and prototype pond as well as the corresponding flow characteristics are given in Table 1.

\section{Experimental Setup}

The University of Nigeria, Nsukka, Nigeria treatment plant that supplied the influent to the solar enhanced waste stabilization ponds consists of a screen $(6 \mathrm{~mm}$ bar racks set at $12 \mathrm{~mm}$ centre) followed by two imhoff tanks, each measuring about $6.700 \mathrm{~m} \times 4.700 \mathrm{~m} \times 10 \mathrm{~m}$, and then by two facultative ponds in series. Six ponds were connected to one sewage storage tank $(1.2 \mathrm{~m} \times 0.5 \mathrm{~m} \times 0.5 \mathrm{~m})$ that receives its influent from an overhead storage tank $(1.2 \mathrm{~m} \mathrm{x}$ $1.5 \mathrm{~m} \times 1.5 \mathrm{~m})$ were constructed for the experiment. Five (5) out of the six ponds were constructed with a tilt frame at $45^{\circ}$ for fixing the 
solar reflectors each of size $0.2 \mathrm{~m}$ by $1.0 \mathrm{~m}$. All the ponds were operated at a detention time of $168 \mathrm{hrs}=0.42 \mathrm{hrs}$ (relationship $=1 / 400$ ) for the model. The detailed descriptions of the various ponds are explained in Table 2.

The six ponds were filled with sewage from the second facultative pond through a sewage storage tank. Storage tanks were fed continuously by an overhead storage tank which in turn was filled with sewage from a facultative The six ponds were filled with sewage from the second facultative pond through a sewage storage tank. Storage tanks were fed continuously by an overhead storage tank which in turn was filled with sewage from a facultative pond through an underground pipe, with the aid of a water pump being powered by a generator. The pictorial and schematic diagram of the experimental setup is shown in Figures 1 and 2, respectively.

\section{Sample Analysis}

Seven samples were collected weekly during the period from October 2008 until September

Table 1: Prototype to model relationships on kinematics similarity (Reynolds Model) law

\begin{tabular}{|c|c|c|c|c|c|}
\hline Parameter & Unit & Equation & Relationship & Prototype & Model \\
\hline Length, L & $\mathrm{M}$ & $\alpha$ & $1 / 20$ & 20 & 1 \\
\hline Width, W & $\mathrm{M}$ & $\alpha$ & $1 / 20$ & 8 & 0.4 \\
\hline Depth, D & M & $\alpha$ & $1 / 20$ & 4 & 0.2 \\
\hline Surface Area, A & $\mathrm{M}^{2}$ & $\alpha^{2}$ & $1 / 400$ & 160 & 0.4 \\
\hline Volume, V & $\mathrm{M}^{3}$ & $\alpha^{3}$ & $1 / 8000$ & 640 & 0.08 \\
\hline Ideal detention time, $\mathrm{T}(=\mathrm{V} / \mathrm{Q})$ & hrs & $\alpha^{2}$ & $1 / 400$ & 168 & 0.42 \\
\hline Influent rate, $\mathrm{Q}$ & $\mathrm{M}^{3} / \mathrm{d}$ & $\alpha$ & $1 / 20$ & 264 & 13.2 \\
\hline $\begin{array}{l}\text { Average theoretical Velocity } \\
(\mathrm{U}=\mathrm{QD} / \mathrm{V})\end{array}$ & $\mathrm{M} / \mathrm{d}$ & $\alpha^{-1}$ & 20 & $4.125 \times 10^{-2}$ & $8.25 \times 10^{-1}$ \\
\hline $\begin{array}{l}\text { Average Pond Reynold's No. } \\
\operatorname{Re}\left(\operatorname{Re}=\mathrm{UR}_{\mathrm{h}} /(y\right. \\
\text { Average Froude No. }\end{array}$ & - & $\alpha^{0}$ & 1 & 116 & 116 \\
\hline $\mathrm{Fr}=\mathrm{u} /\left(\mathrm{gR}_{\mathrm{h}}\right)^{0.5}$ & - & $\alpha^{-2}$ & 40 & $1.54 \times 10^{-5}$ & $6.21 \times 10^{-4}$ \\
\hline
\end{tabular}

Table 2: Detailed Description of the Various Ponds

\begin{tabular}{cclc}
\hline $\begin{array}{c}\text { Experimental } \\
\text { Ponds }\end{array}$ & Size (m) & Characteristics & Purpose \\
\hline A & $1 \times 0.4 \times 0.2$ & No solar reflector & Control \\
B & $1 \times 0.4 \times 0.2$ & Solar reflector & Measure the effect of solar reflector \\
C & $1 \times 0.3 \times 0.2$ & Solar reflector & Measure the effect of solar reflector \\
D & $1 \times 0.5 \times 0.2$ & Solar reflector & Measure the effect of solar reflector \\
E & $1 \times 0.2 \times 0.2$ & Solar reflector & Measure the effect of width \\
F & $1 \times 0.6 \times 0.2$ & Solar reflector & Measure the effect of solar reflector \\
\hline
\end{tabular}




\section{Utsev and Agunwamba}

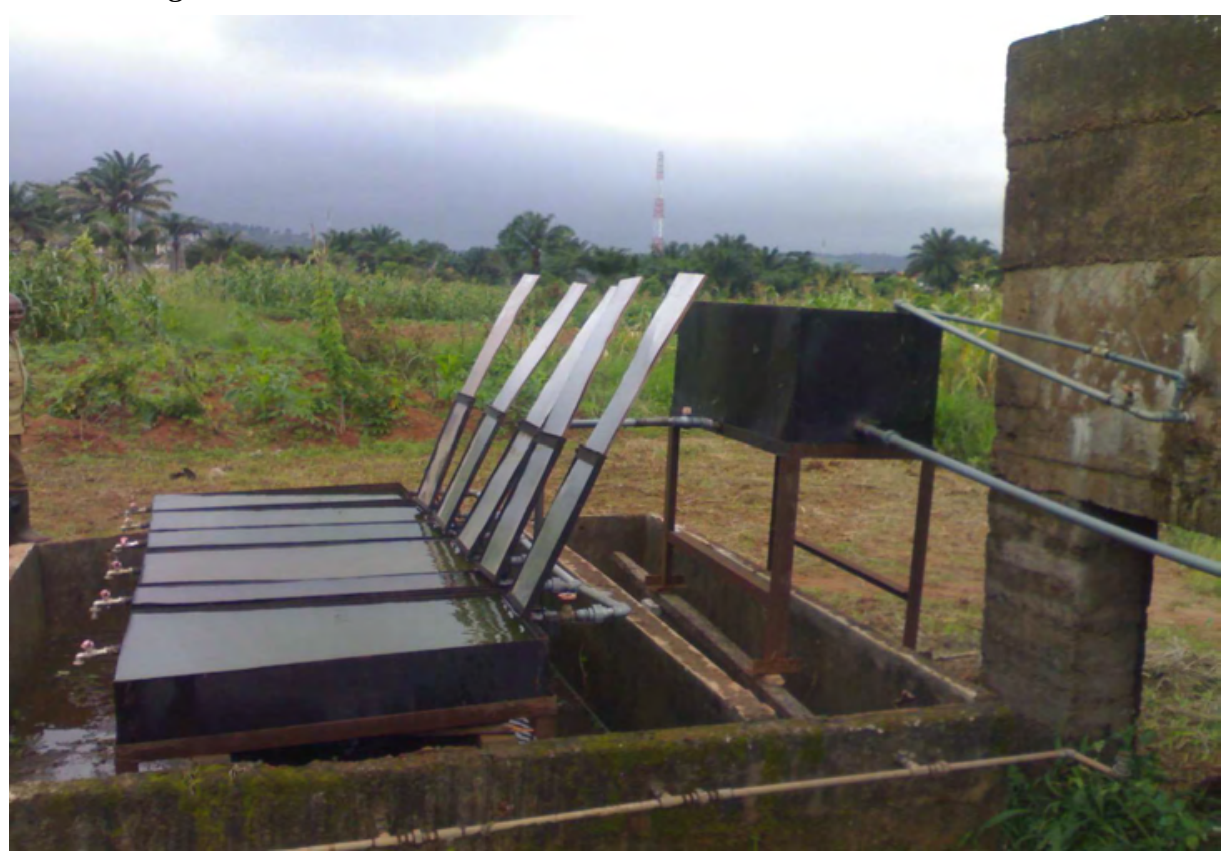

Fig. 1: Experimental setup

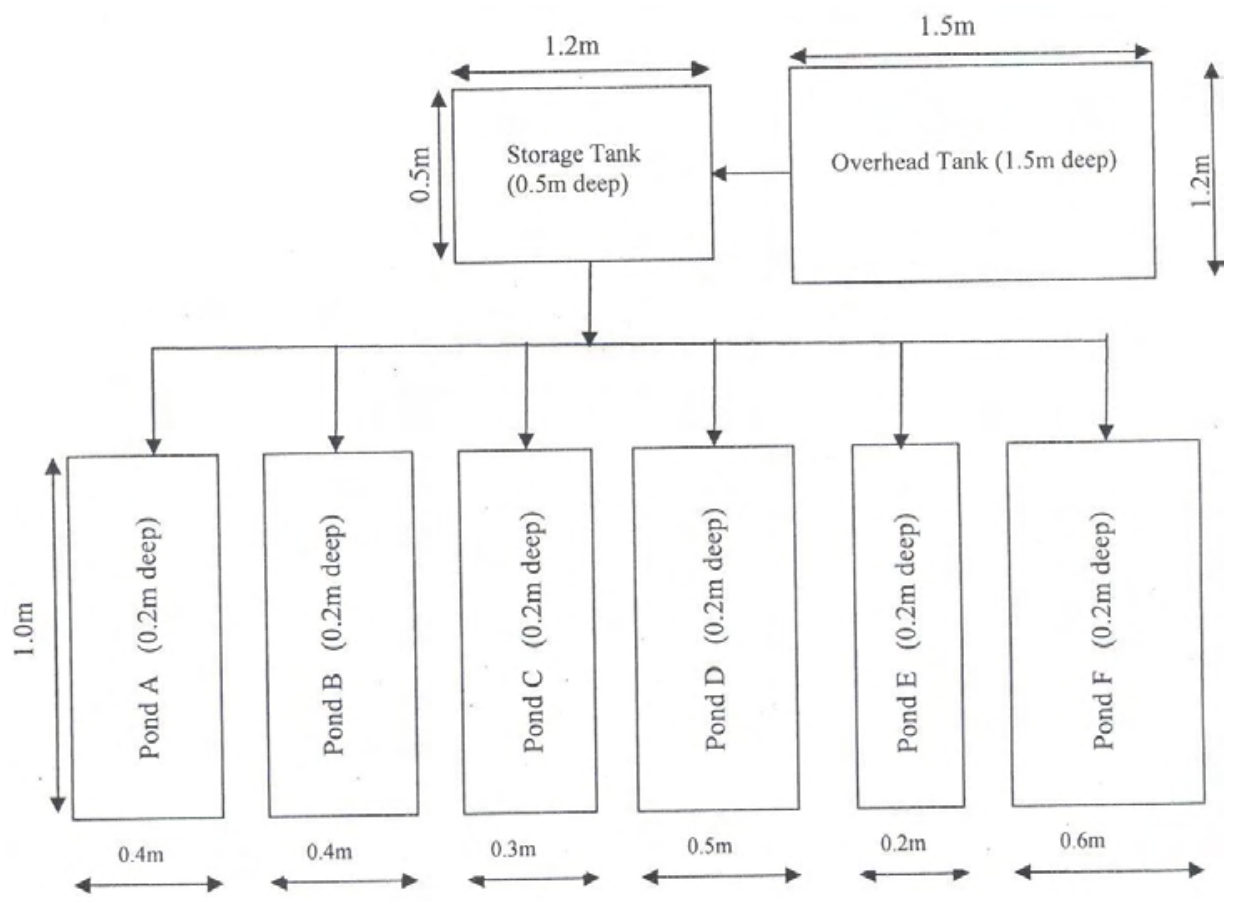

Fig. 2: Schematic diagram of experimental setup 
2009 from the five different solar ponds, the control pond and one from the outlet of the storage tank for laboratory analysis to determine the concentrations of $\mathrm{BOD}_{5}, \mathrm{COD}, \mathrm{DO}$, algae count, faecal coliform, E-Coli, suspended solids, temperature and $\mathrm{pH}$. Ponds of different widths were chosen in order to analyse the effect of length to width ratio on the efficiency of solar enhanced treatment in WSP.

Dissolved oxygen (DO) was measured at the point of collection using a HI 9142 water multiparameter testing meter, while BOD was obtained with the use of the same meter at the laboratory. The other parameters were obtained from sewage samples collected for laboratory analysis which were analysed immediately they were brought into the sanitary laboratory based on the Standard Methods (APHA, 1998).

\section{RESULTS AND DISCUSSIONS}

The experimental results are presented in Fig. 3 to 20 . Figures 3 to 11 depict the weekly variations of treatment efficiencies of the SEWSP with respect to $\mathrm{pH}$, DO, coliform, E-coli, BOD, COD, algae count and Suspended Solids removal, respectively. Figure 12 demonstrates the effect of pond width on removal efficiencies in the SEWSPs, while Fig. 13 to 20 illustrates the effect of length/ width ratio on removal efficiencies in the SEWSPs with solar radiation. The various graphs are discussed below.

\section{Effect of Width}

There was a consistent pattern of increase in efficiency for all the test indicators with decreasing width for the solar ponds E, C, B, D and $\mathrm{F}$. Indicators like temperature, algae concentration, dissolved oxygen increases in concentration as the width decreases (Fig. 3 - 6). This is because, as the surface area decreases, the solar radiation gets concentrated and increases the rate of photosynthesis which enables the algae to release oxygen needed by aerobic bacteria. The oxygen released by the algae as a result of photosynthesis is utilized by bacteria for aerobic degradation of organic matter which releases carbondioxide, ammonia and phosphate as by products which are in turn utilized by algae for its growth.

The results also showed that, the removal of coliform bacteria was higher in pond $\mathrm{E}$ with the smallest width $(0.2 \mathrm{~m})$ (Fig. 7). The average concentrations of coliform bacteria in ponds A, $\mathrm{B}, \mathrm{C}, \mathrm{D}, \mathrm{E}$ and F were $1100 / 100 \mathrm{ml}, 150 / 100 \mathrm{ml}$, 93/100ml, 210/100ml, 75/100ml, 460/100ml respectively. Similar result was obtained for E. Coli (Fig. 8) where the minimum and maximum effluents are $21 / 100 \mathrm{ml}$ and $93 / 100 \mathrm{ml}$, $9 / 100 \mathrm{ml}$ and $28 / 100 \mathrm{ml}, 7 / 100 \mathrm{ml}$ and $21 / 100 \mathrm{ml}$, $11 / 100 \mathrm{ml}$ and $43 / 100 \mathrm{ml}, 4 / 100 \mathrm{ml}$ and $14 / 100 \mathrm{ml}, 14 / 100 \mathrm{ml}$ and $64 / 100 \mathrm{ml}$ for ponds A, $\mathrm{B}, \mathrm{C}, \mathrm{D}, \mathrm{E}$ and $\mathrm{F}$ respectively. These results were corroborated by the higher average temperature $\left(26.1^{\circ} \mathrm{C}, \quad 27.5^{\circ} \mathrm{C}, \quad 28.2^{\circ} \mathrm{C}, \quad 27.2^{\circ} \mathrm{C}\right.$, $30.1^{\circ} \mathrm{C}$ and $26.3^{\circ} \mathrm{C}$ ) observed in ponds $\mathrm{A}, \mathrm{B}, \mathrm{C}$, D, E and F respectively (Sinton et al., 2002).

The average suspended solids removal efficiency was higher in pond $E$ because of its smaller surface area as compare to ponds A, B, $\mathrm{C}, \mathrm{D}$ and $\mathrm{F}$ (Fig. 9). The minimum suspended solids effluent was $11 \mathrm{mg} / \mathrm{l}, 7 \mathrm{mg} / \mathrm{l}, 6 \mathrm{mg} / \mathrm{l}, 9 \mathrm{mg} /$ $1,3 \mathrm{mg} / \mathrm{l}$ and $10 \mathrm{mg} / \mathrm{l}$ for ponds $\mathrm{A}, \mathrm{B}, \mathrm{C}, \mathrm{D}, \mathrm{E}$ and $\mathrm{F}$ whereas the maximum values were $30 \mathrm{mg} / 1,24 \mathrm{mg} / \mathrm{l}, 21 \mathrm{mg} / 1,26 \mathrm{mg} / \mathrm{l}, 10 \mathrm{mg} / \mathrm{l}$ and $27 \mathrm{mg} / \mathrm{l}$ for ponds A, B, C, D, E and F respectively. Similar result was obtained for $\mathrm{BOD}_{5}$ (Fig. 10) where the minimum and maximum concentrations were $115 \mathrm{mg} / \mathrm{l}$ and $317 \mathrm{mg} / \mathrm{l}$, $101 \mathrm{mg} / \mathrm{l}$ and $281 \mathrm{mg} / \mathrm{l}, 92 \mathrm{mg} / \mathrm{l}$ and $243 \mathrm{mg} / \mathrm{l}$, $108 \mathrm{mg} / \mathrm{l}$ and $293 \mathrm{mg} / \mathrm{l}, 81 \mathrm{mg} / \mathrm{l}$ and $156 \mathrm{mg} / \mathrm{l}$, $110 \mathrm{mg} / \mathrm{l}$ and $300 \mathrm{mg} / \mathrm{l}$ for ponds A,B,C,D,E and $\mathrm{F}$ respectively. For COD, average values ranged from $224 \mathrm{mg} / \mathrm{l}$ to $584 \mathrm{mg} / \mathrm{l}, 182 \mathrm{mg} / \mathrm{l}$ to $498 \mathrm{mg} / \mathrm{l}, 170 \mathrm{mg} / \mathrm{l}$ to $446 \mathrm{mg} / \mathrm{l}, 186 \mathrm{mg} / \mathrm{l}$ to $526 \mathrm{mg} / \mathrm{l}, 156 \mathrm{mg} / \mathrm{l}$ to $322 \mathrm{mg} / \mathrm{l}$ and $210 \mathrm{mg} / \mathrm{l}$ to $568 \mathrm{mg} / \mathrm{l}$ for ponds A, B, C, D, E and F respectively (Fig. 11). The average removal efficiencies for all the parameters are given in Table 3.

\section{Solar Effect Consideration}

Pond $\mathrm{E}$ with the smallest width of $0.2 \mathrm{~m}$ had the Highest efficacy among ponds B, C, D, E, and $F$ (Fig. 12) with respect to all the parameters 


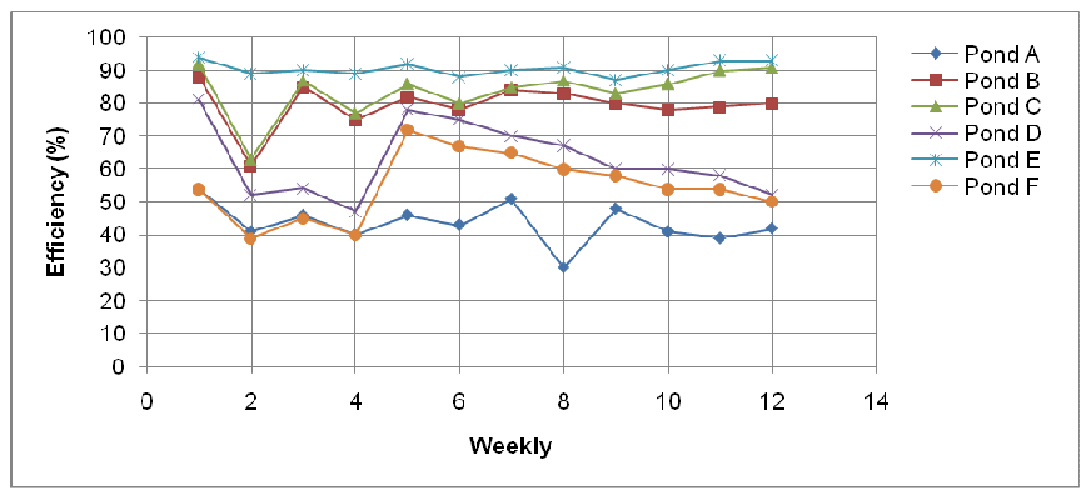

Fig. 3: Efficiency of pH variation with time

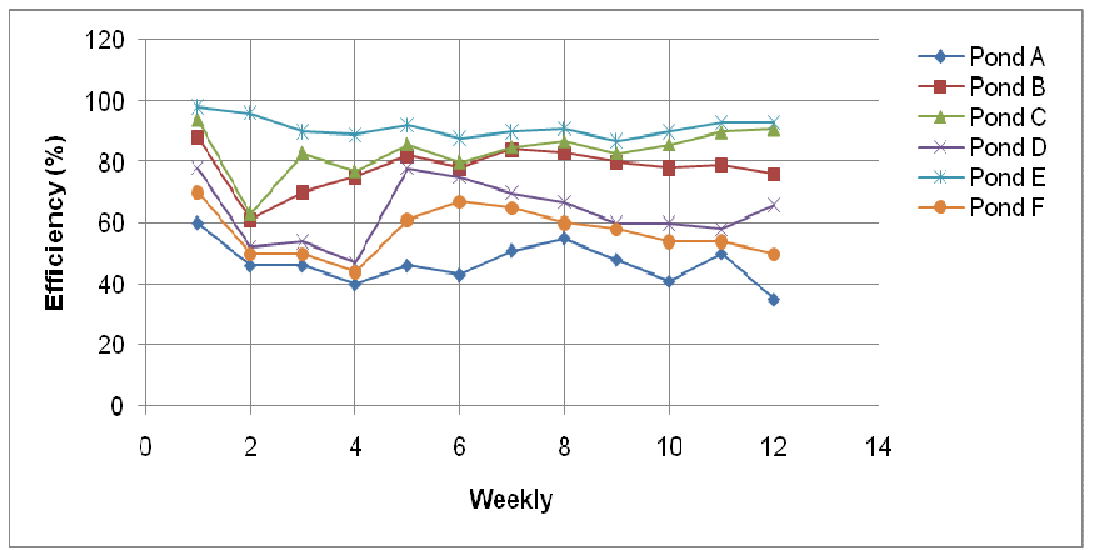

Fig. 4: Efficiency of Temp. variation with time

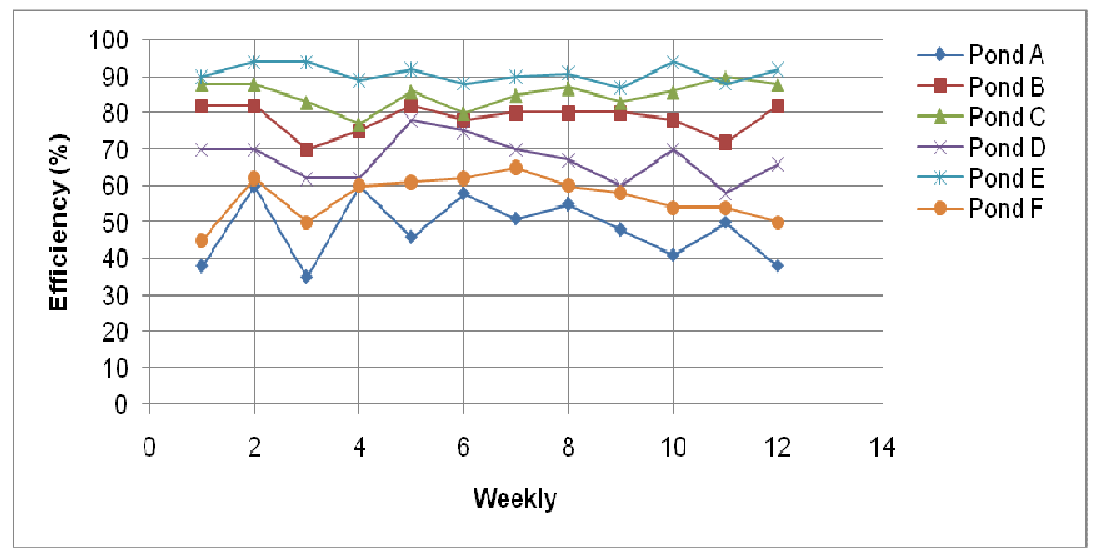

Fig. 5: Efficiency of Algal conc. variation with time 


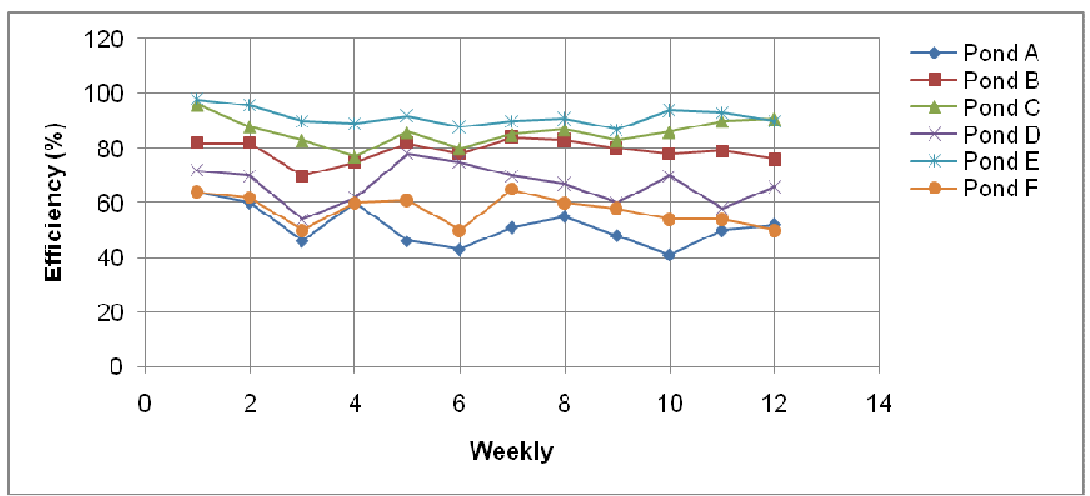

Fig. 6: Efficiency of DO increase with time

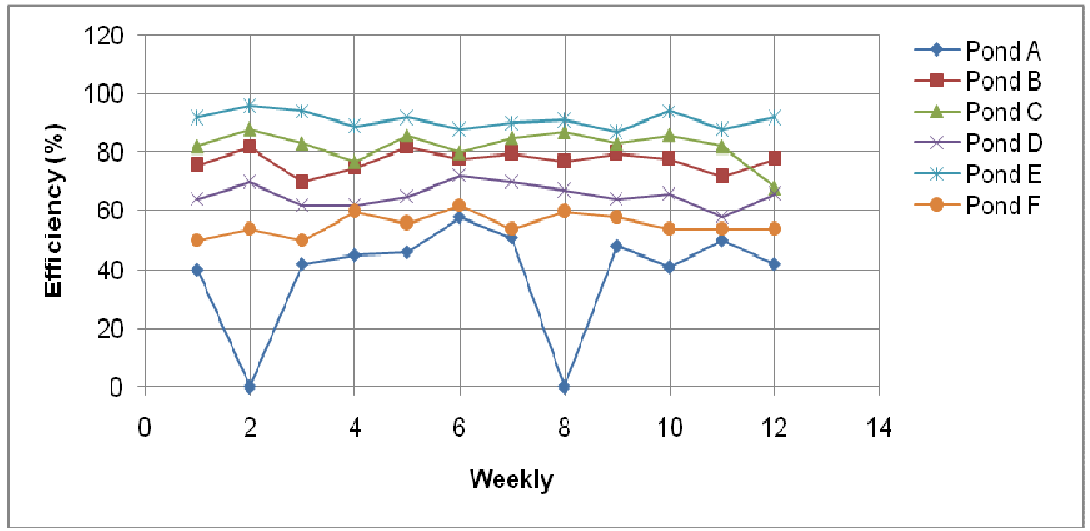

Fig. 7: Efficiency of Coliform variation with time

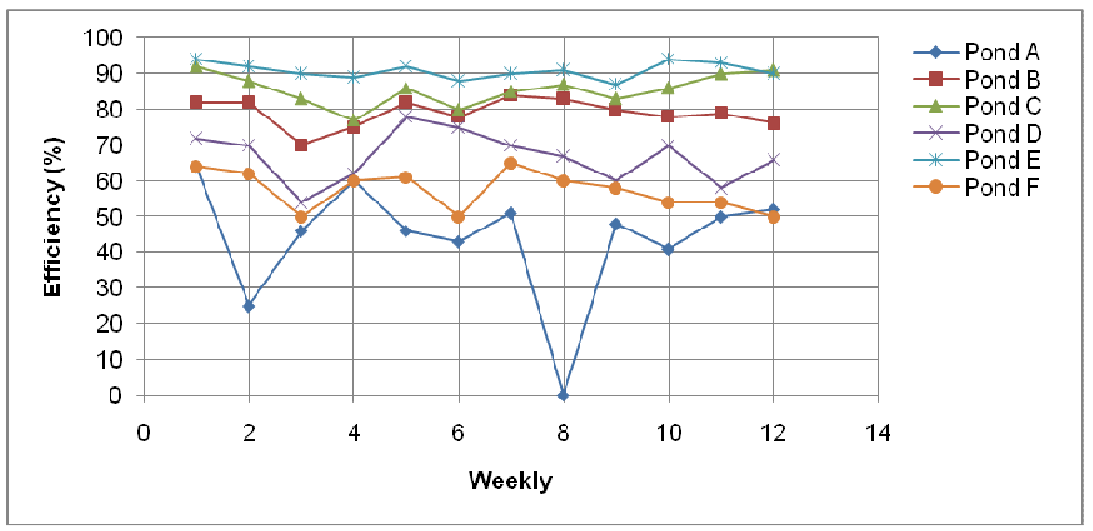

Fig. 8: Efficiency of E-coli variation with time 


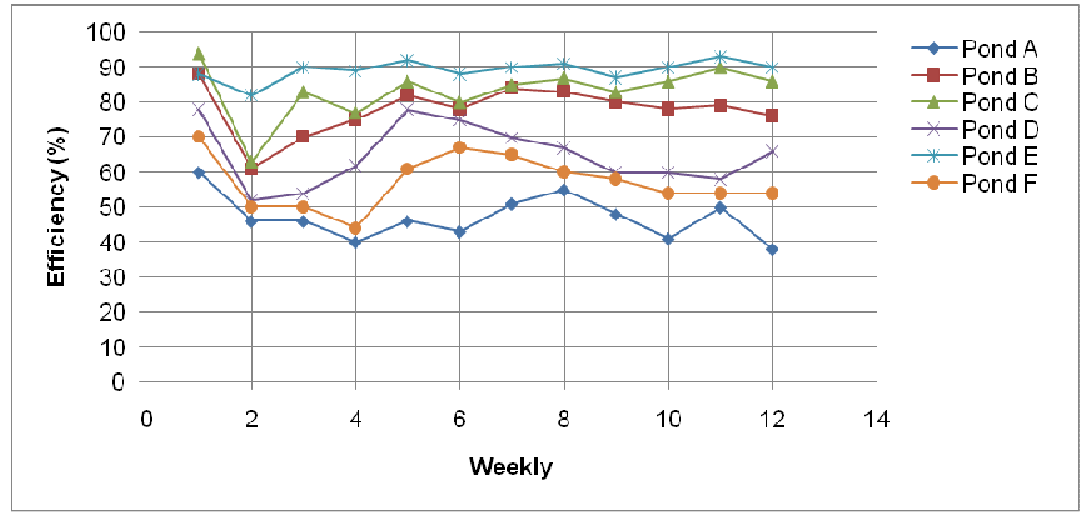

Fig. 9: Efficiency of suspended solid variation with time

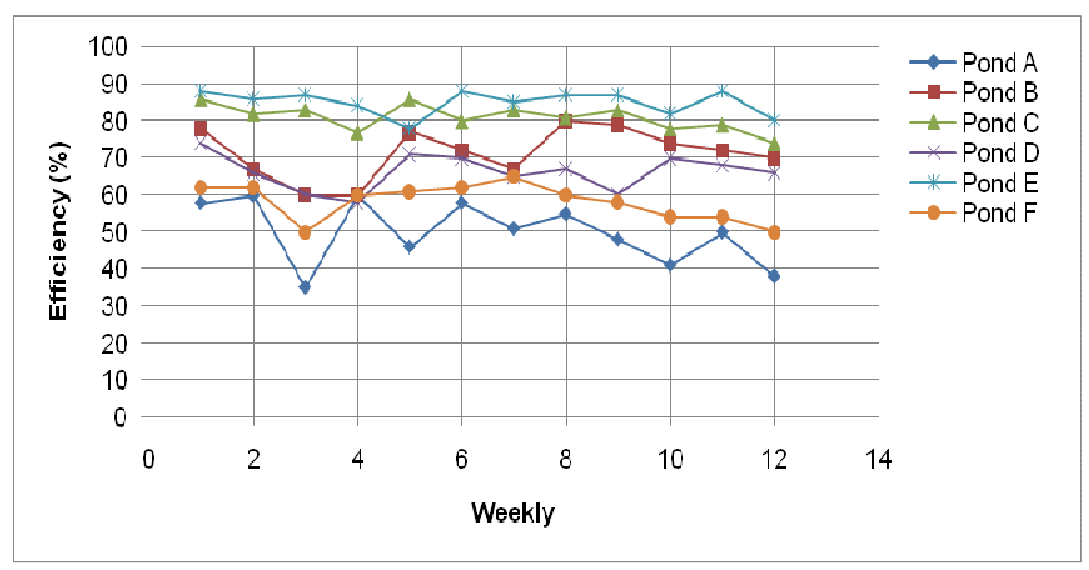

Fig. 10: Efficiency of BOD Variation with time.

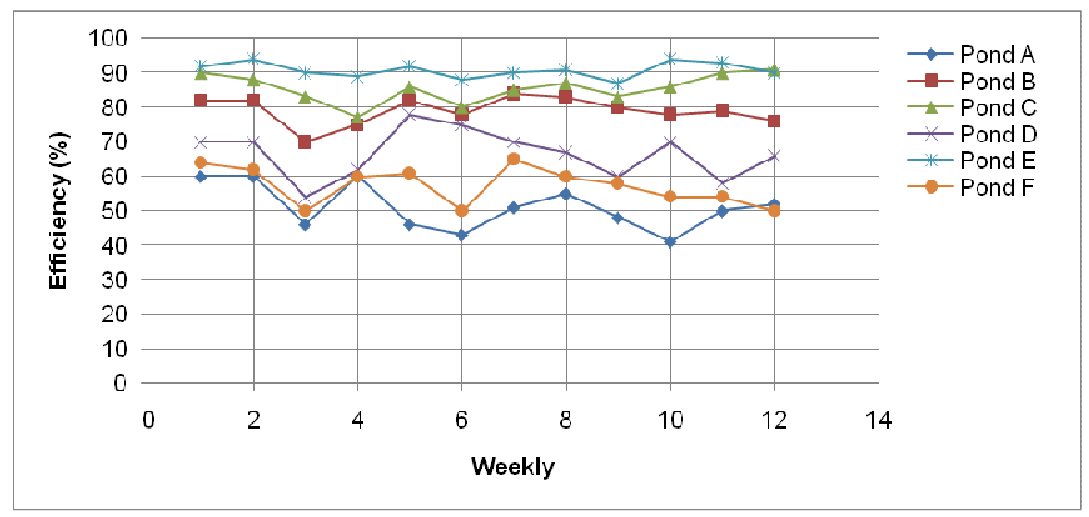

Fig. 11: Efficiency of COD Variation with time 


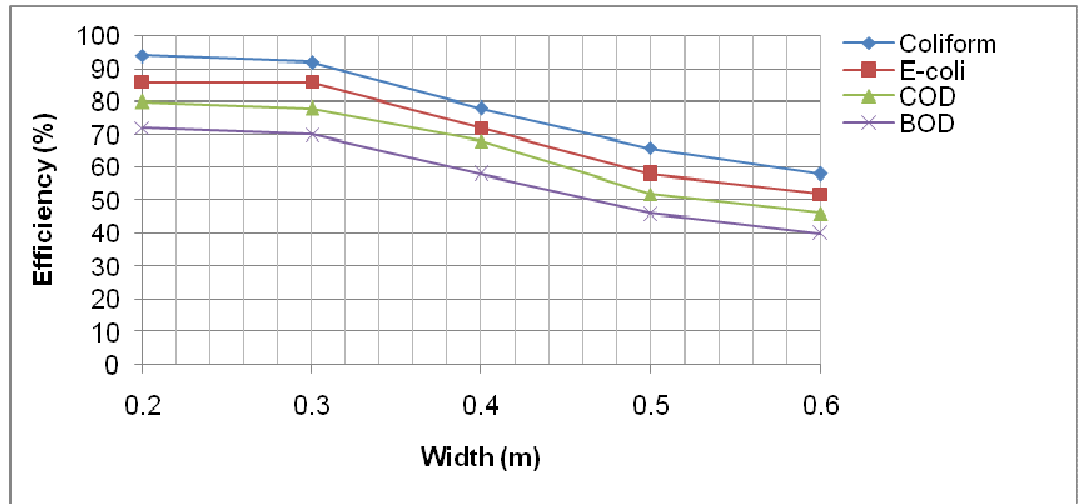

Fig. 12: Efficiency of treatment removal vs width

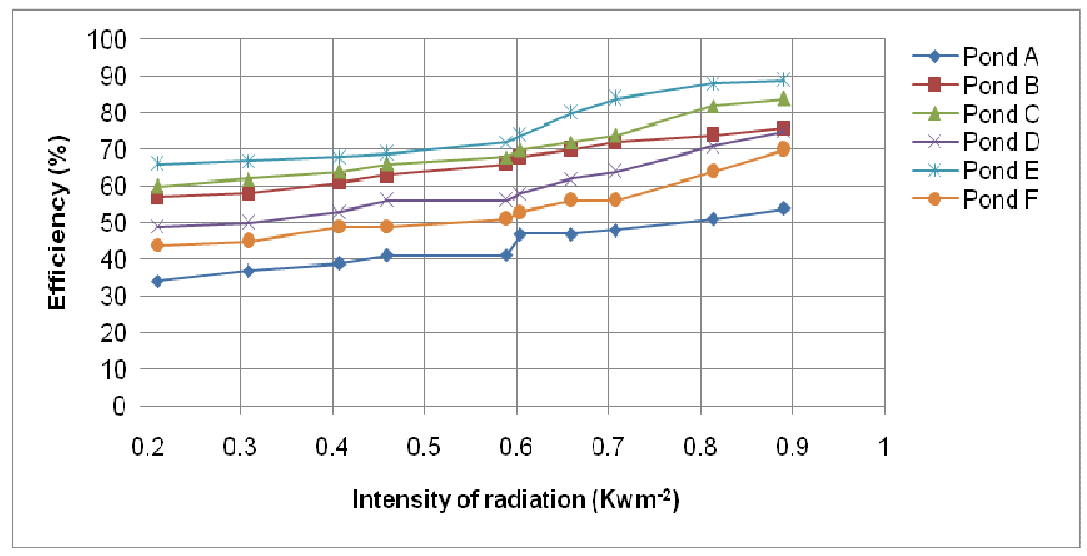

Fig. 13: Efficiency of BOD removal vs solar intensity

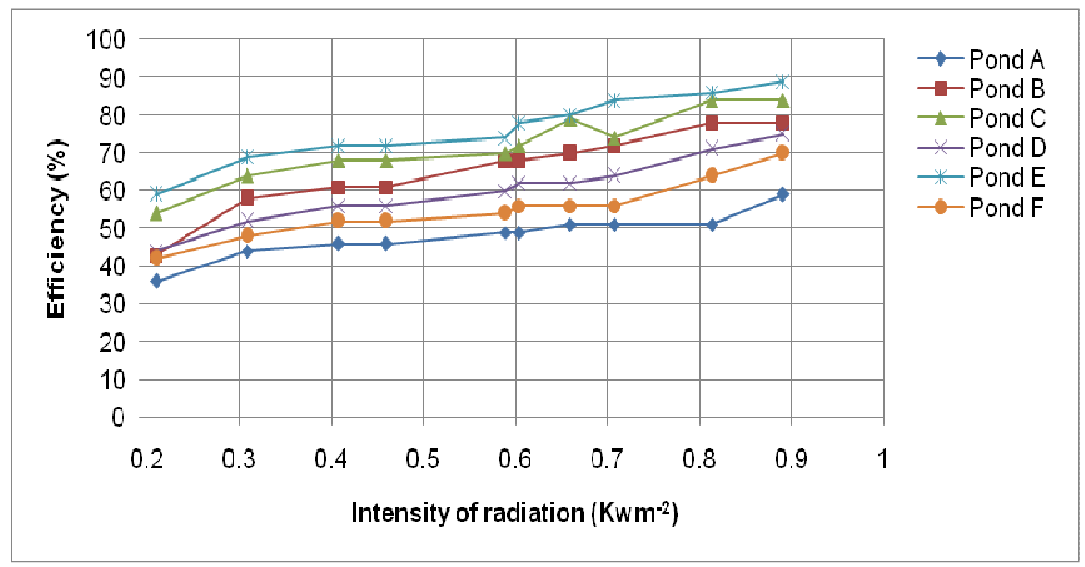

Fig. 14: Efficiency of COD removal vs solar intensity 


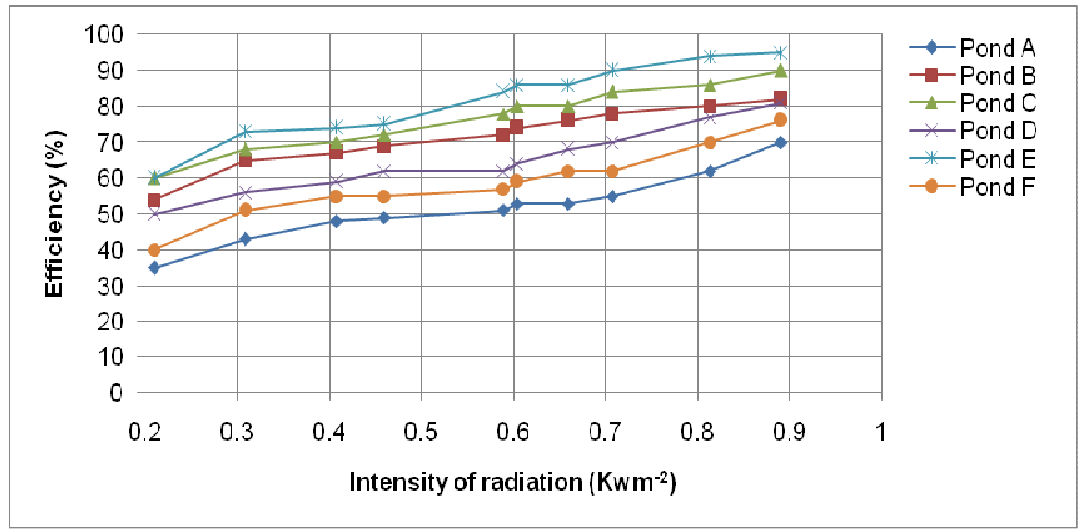

Fig. 15: Efficiency of Coliform removal vs solar intensity

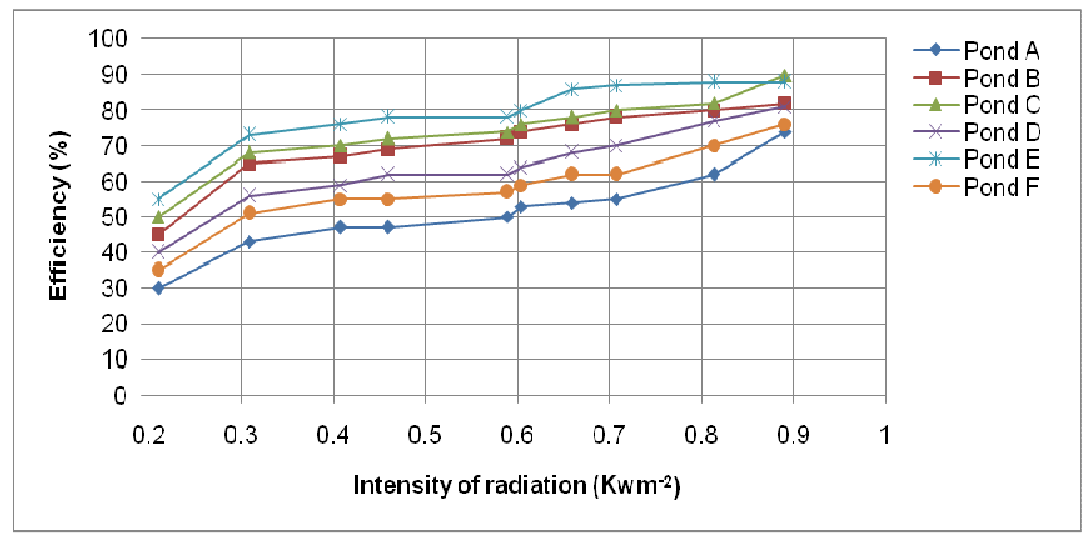

Fig.16: Efficiency of E-coli removal vs solar intensity

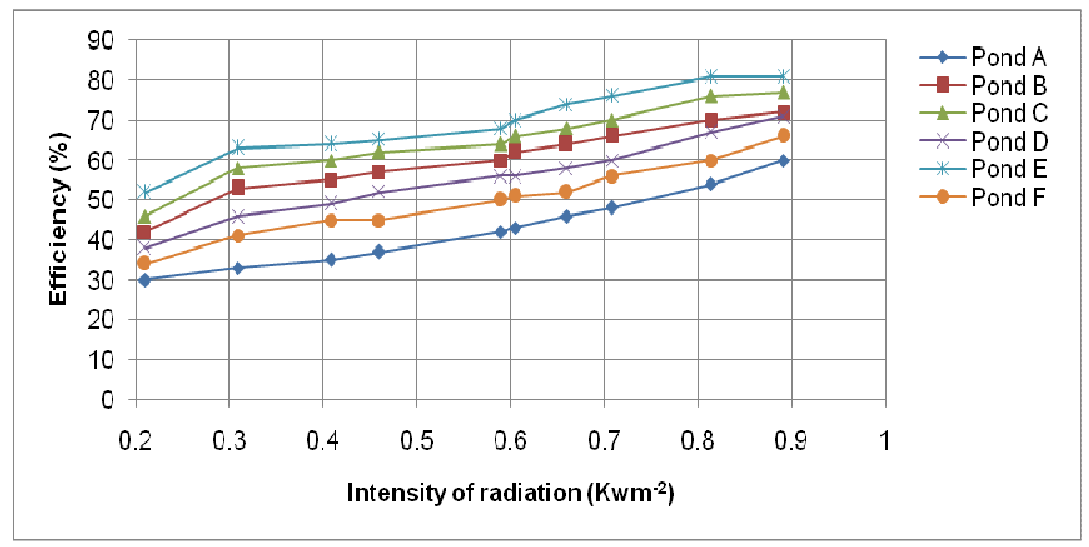

Fig. 17: Efficiency of Suspended Solid removal vs solar intensity

Journal of Science and Technology @ KNUST April 2012 


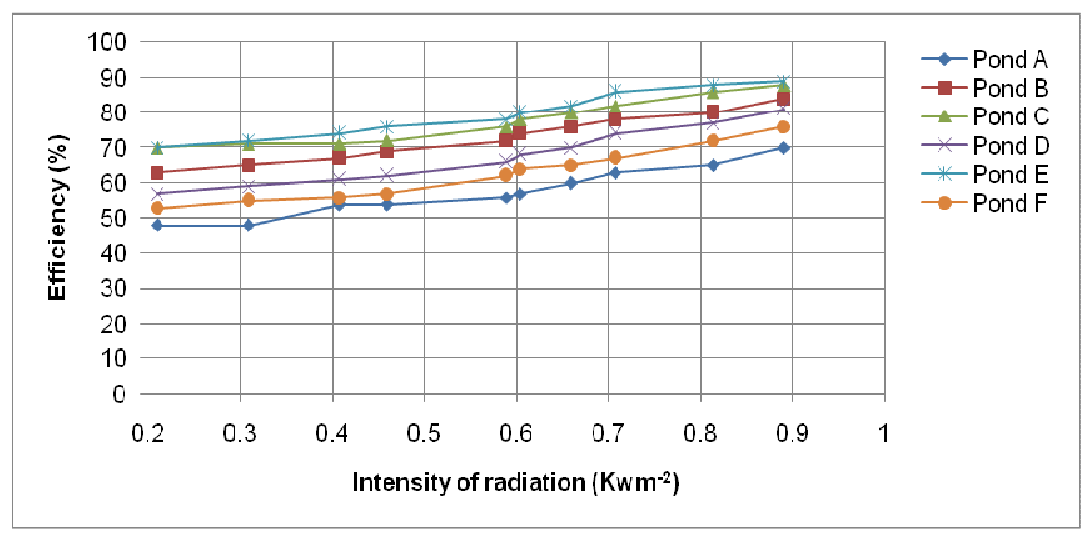

Fig. 18: Efficiency of DO increase vs solar intensity

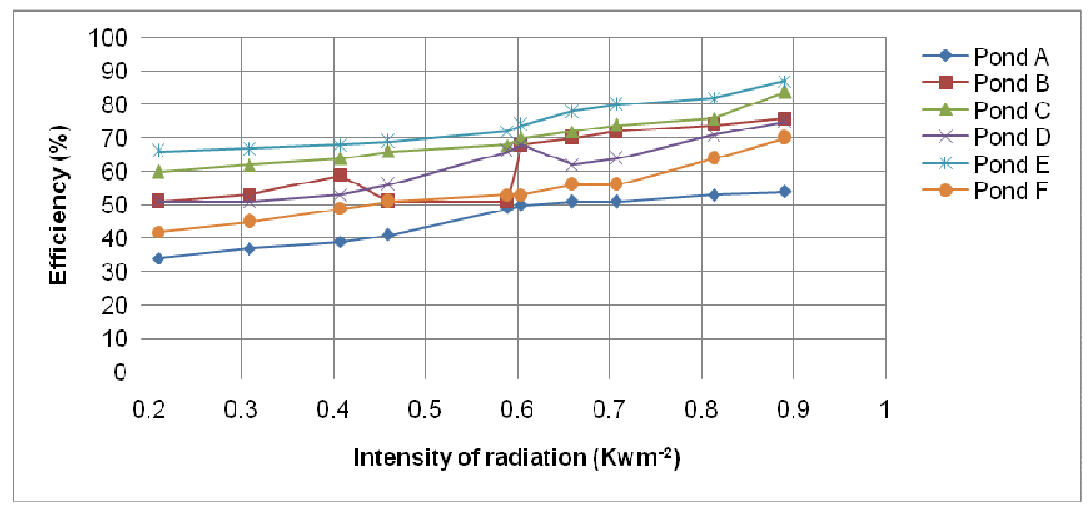

Fig. 19: Efficiency of Algal variation vs solar intensity

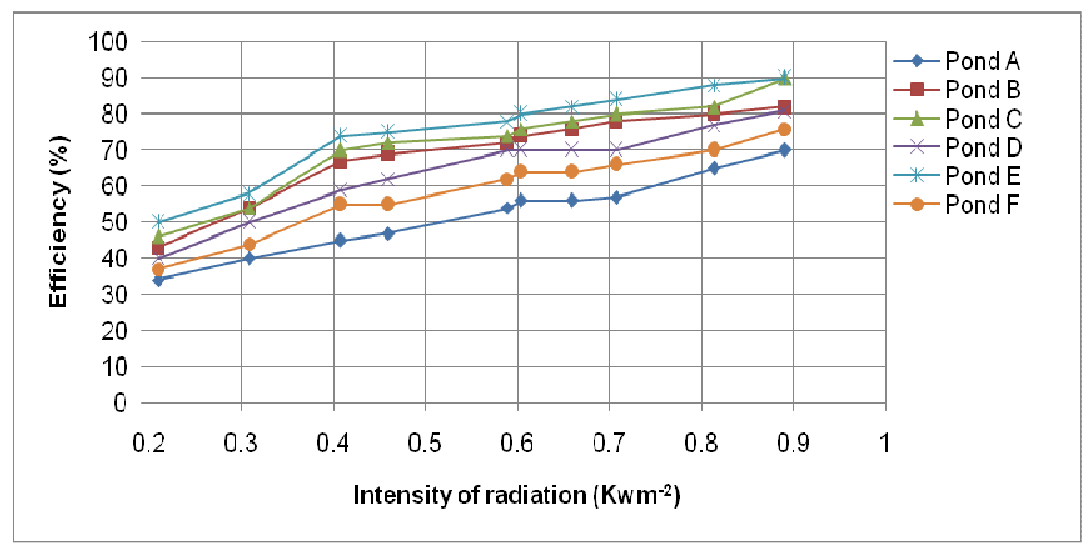

Fig. 20: Efficiency of pH variation vs solar intensity 
Table 3: Average removal efficiencies of the ponds with respect to all the parameters investigated. (Mean \pm Standard deviation)

\begin{tabular}{ccccccccc}
\hline Pond & \multirow{2}{*}{ Coliform } & E.Coli & BOD $_{5}$ & COD & SS & DO & Algal & pH \\
& & & & & & & conc. & \\
\hline A & $53.2 \pm 12.1$ & $51.3 \pm 15.6$ & $48.5 \pm 6.1$ & $45.7 \pm 5.3$ & $49.5 \pm 10.8$ & $7.8 \pm 1.6$ & $17 \pm 12.4$ & $7.9 \pm 1.4$ \\
& & & & & & & & \\
B & $83.2 \pm 10.4$ & $75.6 \pm 11.2$ & $78.2 \pm 11.3$ & $77.9 \pm 12.4$ & $78.4 \pm 10.9$ & $7.1 \pm 1.2$ & $12.0 \pm 10.2$ & $7.4 \pm 1.2$ \\
C & $86.3 \pm 11.2$ & $81.3 \pm 12.3$ & $80.4 \pm 5.2$ & $79.4 \pm 6.7$ & $79.9 \pm 9.9$ & $5.9 \pm 1.4$ & $11.1 \pm 18.1$ & $6.3 \pm 1.6$ \\
D & $77.6 \pm 11.8$ & $76.8 \pm 18.9$ & $75.4 \pm 10.6$ & $74.2 \pm 7.9$ & $74.3 \pm 10.8$ & $7.1 \pm 1.9$ & $14.6 \pm 11.4$ & $7.5 \pm 1.7$ \\
E & $89.1 \pm 10.8$ & $84.3 \pm 11.1$ & $82.7 \pm 6.4$ & $80.4 \pm 14.7$ & $81.8 \pm 12.5$ & $5.7 \pm 1.4$ & $9.1 \pm 18.1$ & $6.1 \pm 1.4$ \\
F & $56 \pm 12.6$ & $51.7 \pm 19.1$ & $51.9 \pm 6.3$ & $50.7 \pm 7.9$ & $50.8 \pm 11.5$ & $7.7 \pm 1.8$ & $16 \pm 12.4$ & $7.7 \pm 1.3$ \\
\hline
\end{tabular}

investigated. Application of the same reflector in all the ponds produces the highest intensity per unit volume in pond $\mathrm{E}$, this is because, the amount of solar radiation entering the ponds was the same and gets concentrated in pond $\mathrm{E}$ due to its smaller width. This increases the temperature in pond $\mathrm{E}$ by $1.9^{\circ} \mathrm{C}$ above all the other ponds. The average temperatures of ponds $\mathrm{A}$, $\mathrm{B}, \mathrm{C}, \mathrm{D}, \mathrm{E}$ and and $\mathrm{F}$ were $25.1^{\circ} \mathrm{C}, 27.5^{\circ} \mathrm{C}$, $28.2^{\circ} \mathrm{C}, 27.2^{\circ} \mathrm{C}, 28.8^{\circ} \mathrm{C}$ and $26.3^{\circ} \mathrm{C}$ respectively. The temperature values agreed with variation of dissolved oxygen in these ponds. Pond E had the least value while pond A had the highest since the solubility of oxygen decreases with increase in temperature. Figure 13 to 20 show the variations of removal efficiency with solar intensity. Generally, efficiency increases with the amount of solar radiation for each of the parameters investigated as the width decreases.

\section{CONCLUSION}

In the investigation of aspect ratio (Length to Width ratio) in solar enhanced waste stabilization ponds (SEWSPs) in order to understand its effects on wastewater treatment efficiency, experimental investigations were carried out using solar enhanced WSP for treatment of sewage effluent from a facultative pond in the University of Nigeria, Nsukka. Ponds of different widths were used in order to investigate the effect of width on treatment efficiency. Five solar ponds (B, C, D, E and F) were fitted with solar reflectors in order to concentrate the incident solar radiation, while pond $\mathrm{A}$, without a reflector, was used as control experiment.

Wastewater samples collected from the inlet and outlet of the SEWSPs were examined for physico-chemical and biological characteristics for a period of twelve (12) months. The parameters examined were Temperature, $\mathrm{pH}$, detention time, total suspended solids, dissolved oxygen, biochemical oxygen demand $\left(\mathrm{BOD}_{5}\right)$, chemical oxygen demand (COD), algae count, faecal coliform and E-Coli. From the experimental results of comparative analysis revealed that, the efficiencies of the SEWSPs with respect to these parameters fluctuated with width variation, with SEWSP of width $0.2 \mathrm{~m}$ giving the highest level of bacteria reduction.

\section{RECOMMENDATION}

From research, the rate of microbial activities 


\section{Ustev and Agunwamba}

increases as waste stabilization ponds are being fitted with solar reflectors (Agunwamba et al., 2009). Therefore, the present study now recommends a length/ width ratio of 1:0.2 to be used in the design of SEWSPs for maximum treatment efficiency.

\section{ACKNOWLEDGEMENTS}

This research was supported by National Centre for Energy Research and Development, University of Nigeria, Nsukka, Nigeria by providing the facilities for research. We also appreciate the financial assistance of Chief Joseph Kaaba of Finance and Supply Department, National Assembly, Abuja-Nigeria.

\section{REFERENCES}

Agunwamba, J. C., Utsev, J. T. and Okonkwo, W. I. (2009). Solar Enhanced Wastewater Treatment in Waste Stabilization Ponds. Water Environment Research, 81(5): 540-545.

Agunwamba, J. C. (2006). Effect of the location of the inlet and outlet structures on short -circuiting: Experimental Investigation. Water Environment Research, 78(6): 580-589.

Agunwamba, J. C. and Tanko, J. A. (2005). Waste stabilization pond design using geometric programming. Technology and Development 9: 123-128.

Agunwamba, J. C. (1992). Field pond performance and design evaluation using physical models. Water Res 26(1): 1403-1407.

Agunwamba, J. C. (2001). Effect of tapering on the performance of waste stabilization ponds. Wat. Res. 35(5): 1191-1200.

APHA (1998). Standard methods for examination of water and wastewater $20^{\text {th }}$ ed. American Public Health Association, AWWA, WPCF, Washington D.C.

Arar, A. (1988). Background to treatment and use of sewage effluent. In: Treatment and use of Sewage Effluent for Irrigation (eds Pescod
M. B. and Arar, A.) Butterworth, Sevenoaks, Kent.

Benchokroun, S., Imziln, B. and Hassani, L. (2003). Solar inactivation of mesophilic Aeromonas by exogenous photooxidation in high-rate algal pond treating wastewater. Microbiol. 94(3): 531-538.

Christian, R., Sabine, W. and Arnulf, M. (2003). A combined system of lagoon and constructed wetland for an effective wastewater treatment. Wat. Res., 37: 2035-2042.

Davies-Colley, R. J., Graggs, R. J., Park, J. and Nagels, J. W. (2005). Optimal characteristics of waste stabilization ponds; recommendations for monitoring. Wat. Sci. Technol. 51 (12): 153-161.

Hamzeh, R. and Pronce, V. (2002). Design performance of waste stabilization ponds. mcgrawhill, New York, USA.

Mara, D. and Pearson, H. (1998). Design man ual for waste stabilization ponds in Mediterranean countries, Leeds Lagoon Technology International Ltd. Leed, Uk.

Mara, D. D., Pearson H. W. and Silva, S. A. (1983), Brazilian stabilization pond research suggest low-cost urban applications. World Water 6: 20-24.

Marais, G. V. R. (1966). New Factors in the Design, Operation and Performance of Waste -stabilization Ponds. World Health Organization Bulletin, 34: 737-763.

Maresco do Monte, M. H. F. and Mara, D. D. (1987). The hydraulic performance of waste stabilization ponds in Portugal. Water Sci. 19 (12): 219-227.

Pearson, H. W., Silva, S. A. and Athayde, G. B. (2005). Implications for physical design: the effects of depth on the performance of waste stabilization ponds. Wat. Sci. Technol. 
51(12): 69-74.

Polprasert, C., Dissanayake, M. G. and Thanh, N. C. (1983). Bacterial die-off kinetics in waste stabilization ponds. J. Water Pollut. Control Fed. 55(3): 285-296.

Sarikaya, H. Z. and Saatci, A. M. and (1987). Bacterial die-off kinetics in waste stabilization ponds. ASCE J. Engng. Div. 113(2): 366 -382 .

Shelef, G., Juanico, M. and Vikinsky, M.
(1987). Reuse of stabilization pond effluent. Water Sci. Technol. 19(12): 229-235.

Sinton, L. W, Hall, C. H, Lynch, P. A. and Davies-Colley, R. J. (2002). Sunlight inactivation of fecal indicator bacteria and bacteriophages from waste stabilization effluent in fresh and saline waters. Appl. Environ. Microbiol. 68(3): 1122-1131.

Strong, S. J. and Scheller, W. G. (1993). The Solar Electric House, Sustainability Press, New York. 